ks. Bartosz Trojanowski ${ }^{1}$

https://orcid.org/0000-0003-0158-1647; b.trojanowski@hadak.pl

Papieski Wydział Teologiczny we Wrocławiu

\title{
Teologia sakramentu święceń ze szczególnym uwzględnieniem stopnia diakonatu na podstawie zmian w 2009 roku w kan. 1008 oraz 1009 KPK
}

\section{Streszczenie}

Problematyka diakonatu stanowi jedną z kwestii teologicznych, które nadal wymagają głębokiej refleksji. Dyskusja na ten temat powraca, chociaż zmierzając w różnych, często przeciwnych kierunkach. Zmiany w Kodeksie prawa kanonicznego wprowadzone przez dokument Benedykta XVI Omnium in mentem nie dotyczą tylko samej kwestii diakonatu. Interwencja papieska w prawo kanoniczne przyczyniła się nie tylko do ponownego odczytania ostatniego Soboru w kwestii diakonatu, ale także wszystkich trzech stopni sakramentu święceń (różnic między nimi i sakramentalnego charakteru). Innym aspektem jest kapłaństwo powszechne i kapłaństwo służebne, relacja i różnice pomiędzy nimi. Wyznaczenie przez papieża Benedykta XVI kierunku do pogłębionej refleksji doprowadziło nas do tezy, iż diakonat, mimo że stanowi pierwszy stopień sakramentu święceń, nie włącza jeszcze do kapłaństwa hierarchicznego, a przez to diakon nadal uczestniczy w kapłaństwie powszechnym.

Słowa kluczowe: sakrament święceń, kapłaństwo powszechne, kapłaństwo służebne, diakonat

1 Ks. Bartosz Trojanowski - dr, absolwent Papieskiego Uniwersytetu Santa Croce w Rzymie (teologia dogmatyczna) oraz Papieskiego Uniwersytetu Gregoriańskiego w Rzymie (prawo kanoniczne). 


\begin{abstract}
The Theology of the Sacrament of Holy Orders, with Particular Emphasis on the Degree of Deaconate, based on the Changes Since 2009 in the can. 1008 and $1009 \mathrm{CIC}$

The problem of the diaconate is one of the theological issues that still require a lot of reflection. The discussion on this topic returns, although often in different, often opposite directions. The changes to the Code of Canon Law introduced by the motu proprio of Benedict XVI Omnium in mentem do not only concern the issue of diaconate. The papal intervention into canon law contributed to the rereading of the last council regarding the diaconate, but also all three degrees of the sacrament of Orders (the differences between them and the sacramental character). Another aspect is the universal priesthood and the ministerial priesthood, the relationship and the differences between them. The direction for deeper reflection by Pope Benedict XVI led us to the thesis that the diaconate, although constituting the first degree of the sacrament of Holy Orders, does not yet include it in the hierarchical priesthood, and thus the deacon still participates in the common priesthood.
\end{abstract}

Keywords: sacrament of the orders, universal priesthood, ministerial priesthood, diaconate

Kwestia diakonatu stanowi częsty temat refleksji teologicznej, wystarczy wspomnieć pogłębione studium biblijne, historyczne, prawne i teologiczne Międzynarodowej Komisji Teologicznej, które jednak nie zakończyło dyskusji w tej kwestii. Potwierdzeniem tego jest wracająca co jakiś czas kwestia roli diakonów w Kościele. Dlatego celem tego artykułu będzie przedstawienie relacji między kapłaństwem powszechnym a kapłaństwem hierarchicznym. Drugi cel rozważań to przedstawienie różnicy między poszczególnymi stopniami sakramentu święceń. W ten sposób zostanie przedstawiony problem stopnia diakonatu, który jest pierwszym stopniem sakramentu święceń, chociaż nie stanowi jeszcze włączenia w kapłaństwo hierarchiczne.

Przyczyną do analizy tejże problematyki jest motu proprio Omnium in mentem, poprzez który papież Benedykt XVI dokonał ingerencji w kształt Kodeksu prawa kanonicznego ${ }^{2}$, dotykając istotnych kwestii

2 Codex Iuris Canonici auctoritate Joannis Pauli PP. II promulgatus, 25.01.1983, „Acta Apostolicae Sedis" 75 (1983), pars 2, s. 1-317; tekst polski: Kodeks prawa kanonicznego, przekład polski zatwierdzony przez Konferencję Episkopatu Polski, Poznań 1984 [dalej: KPK]. 
w teologii święceń. Benedykt XVI, jako wybitny teolog, postanowił poprawić przepisy kodeksu, które dotyczą tego drugiego „sakramentu w służbie komunii" - sakramentu święceń. Wprowadzając zmiany w kan. 1008 oraz 1009 KPK, jako cel postawiono przede wszystkim lepiej wyrazić naukę Soboru Watykańskiego II zawartą w Konstytucji dogmatycznej o Kościele Lumen gentium.

Zmiany dokonane w pierwszym z omawianych kanonów sprawiają, że akcent położony jest teraz tak, aby pomagał lepiej zrozumieć teologiczne znaczenie kapłaństwa powszechnego oraz kapłaństwa służebnego, a także różnicę między nimi. Z kolei w drugim interesującym nas kanonie, dodanie trzeciego paragrafu powoduje, że została podkreślona zasadnicza różnica pomiędzy stopniami biskupa i prezbitera w stosunku do stopnia diakona. Analiza tych zmian w KPK może być podstawą bardziej zaawansowanego studium dogmatycznego i kanonicznego dotyczącego sakramentu święceń.

\section{Kapłaństwo powszechne \\ a kapłaństwo służebne}

Kan. 1008 KPK jest normą kanoniczną, która ma bardziej charakter doktrynalny niż prawny. Podobnie jak w przypadku innych kanonów wprowadzających do odpowiedniego sakramentu, celem jest przedstawienie teologicznego aspektu sakramentu święceń. Jednak po zmianie dokonanej przez Benedykta XVI stanowi on nie tylko kwintesencję teologicznego znaczenia tego sakramentu, wyrażonego w kilku sformułowaniach, ale także podkreśla różnicę między kapłaństwem powszechnym i kapłaństwem służebnym.

W kodeksie znajduje się już norma kanoniczna, która wprowadza rozróżnienie prawne pośród wiernych Ludu Bożego: „z ustanowienia Bożego są w Kościele wśród wiernych święci szafarze, których w prawie nazywa się też duchownymi, pozostałych zaś nazywa się świeckimi” (kan. 207 §1 KPK). Chociaż podkreślono, że jest to rozróżnienie z ustanowienia Bożego, to jednak nie ma tutaj wyjaśnienia w kategoriach teologicznych, a bardziej w kategoriach prawnych. Natomiast w kan. 1008 KPK znajdujemy niewątpliwie kilka elementów teologii sakramentu święceń, które 
mogą przyczynić się do zrozumienia różnicy między kapłaństwem powszechnym a tym służebnym.

W pierwszej kolejności należy odwołać się do tekstu, który w tej kwestii można nazwać źródłowym, pochodzącego z Konstytucji Lumen gentium.

Kapłaństwo zaś powszechne wiernych i kapłaństwo urzędowe, czyli hierarchiczne, choć różnią się istotą a nie stopniem tylko, są sobie jednak wzajemnie podporządkowane; jedno i drugie bowiem we właściwy sobie sposób uczestniczy w jednym kapłaństwie Chrystusowym. Kapłan urzędowy mianowicie, dzięki władzy świętej, jaką się cieszy, kształci lud kapłański i kieruje nim, sprawuje w zastępstwie Chrystusa (in persona Christi) Ofiarę eucharystyczną i składa ją Bogu w imieniu całego ludu; wierni zaś na mocy swego królewskiego kapłaństwa współdziałają w ofiarowaniu Eucharystii, pełnią też to kapłaństwo przez przyjmowanie sakramentów, modlitwę i dziękczynienie, świadectwo życia świątobliwego, zaparcie się siebie i czynną miłość 3 .

Intencją ojców soborowych było najwyraźniej podkreślenie przede wszystkim związku, to znaczy wzajemnego, naprzemiennego podporządkowania kapłaństwa powszechnego i kapłaństwa hierarchicznego jako dwóch sposobów uczestniczenia w jedynym kapłaństwie Chrystusa. Przy tej okazji jednak, została również zaakcentowana różnica istotowa, a nie tylko stopnia, chociaż w tym miejscu nie zostało wyjaśnione, na czym ta różnica polega 4 .

Bardziej tę kwestię różnicy między kapłaństwem powszechnym a tym hierarchicznym podejmują ojcowie Soboru Watykańskiego II, przy okazji pogłębienia zagadnień związanych z kapłaństwem służebnym, nauczając w dekrecie soborowym Presbyterorum ordinis:

Dlatego też kapłaństwo prezbiterów zakłada wprawdzie sakramenty chrześcijańskiego wtajemniczenia, zostaje jednak udzielone przez ten specjalny sakrament, mocą którego prezbiterzy dzięki namaszczeniu Ducha Świętego zostają naznaczeni szczególnym znamieniem i tak upodobniają się do Chrystusa Kapłana, aby mogli działać w zastępstwie Chrystusa Głowy ${ }^{5}$.

3 Sobór Watykański II, Konstytucja dogmatyczna o Kościele Lumen gentium, 10, w: Sobór Watykański II, Konstytucje. Dekrety. Deklaracje, Poznań 2002, s. 105-166 [dalej: LG.].

4 Por. G. Ghirlanda, Il Sacramento dell'ordine e la vita dei chierici, 21.

5 Sobór Watykański II, Dekret o posłudze i życiu kapłanów Presbyterorum ordinis, 2, w: Sobór Watykański II, Konstytucje. Dekrety. Deklaracje, Poznań 2002, s. 487- 517 [dalej: PO]. 
Zatem przyjęcie sakramentu święceń, przynajmniej w stopniu prezbitera, dopiero wtedy uzdalnia chrześcijanina do działania in persona Christi Capitis, a to z tego szczególnego względu, że urząd prezbitera jest ściśle związany z biskupstwem i w ten sposób uczestniczy we władzy świętej, mocą której Chrystus działa w swoim Ciele, którym jest Kościół: buduje je, uświęca i nim rządzi ${ }^{6}$. To zatem jest ta istotna różnica, która powoduje, że to właśnie ci, którzy uczestniczą w kapłaństwie służebnym, mają tę władzę, która pozwala im działać in persona Christi ${ }^{7}$, a przez to upoważnia ich, a przede wszystkim daje im moc do tego, aby ważnie sprawować sakrament Eucharystii.

Wyraźnie o tym wspomina papież Jan Paweł II, który w Christifideles laici podkreśla bardzo istotny aspekt sukcesji apostolskiej, która z pewnością wchodzi w zakres tej różnicy w „istocie”, a nie tylko co do „stopnia”, o której mówił Sobór Watykański II. W adhortacji papieskiej czytamy:

W Kościele istnieją przede wszystkim posługi urzędowe, czyli te, które wywodza się z sakramentu kapłaństwa. Pan Jezus bowiem wybrał i ustanowił Apostołów zarodkiem ludu Nowego Przymierza i zaczątkiem nowej hierarchii, powierzając

6 Por. PO 2.

7 O działaniu kapłana, czyli biskupa i prezbitera, w osobie Chrystusa św. Jan Paweł II pisał w kilku listach wielkoczwartkowych skierowanych do kapłanów: „Kapłan sprawuje Najświętszą Ofiarę in persona Christi” - to znaczy więcej niż „w imieniu” czy „w zastępstwie” Chrystusa. „In persona”, to znaczy: w swoistym sakramentalnym utożsamieniu się z Prawdziwym i Wiecznym Kapłanem, który Sam tylko Jeden jest prawdziwym i prawowitym Podmiotem i Sprawcą tej swojej Ofiary - i przez nikogo właściwie nie może być w jej spełnianiu wyręczony. Tylko On - tylko Chrystus - mógł i wciąż może być prawdziwą i skuteczną „propitiatio pro peccatis nostris... sed etiam totius mundi”. Tylko Jego Ofiara, a nie żadna inna, mogła i może mieć „vim propitiatoriam” - ową moc przebłagalną przed Bogiem, przed Trójcą Przenajświętszą, przed Jej transcendentalną świętością. Uświadomienie sobie tego rzuca pewne światło na charakter i znaczenie Kapłana-liturga, który sprawując Najświętszą Ofiarę, działając ,in persona Christi”, zostaje w sposób sakramentalny (a zarazem w sposób niewymowny) wciągnięty i wprowadzony w to najściślejsze „Sacrum”, w które zarazem wprowadza duchowo wszystkich uczestników eucharystycznego zgromadzenia" (Jan Paweł II, Listy na Wielki Czwartek, 24.02.1980, nr 8, 48). A także w innym liście z 2004 roku papież napisał do kapłanów o tej wielkiej godności i jednocześnie zobowiązaniu: „Urząd kapłański, który nie może nigdy sprowadzać się jedynie do aspektu funkcjonalnego, ponieważ wpisuje się w płaszczyznę «istnienia», czyni kapłana zdolnym do działania in persona Christi i znajduje swój punkt kulminacyjny w momencie, w którym dokonuje on konsekracji chleba i wina, powtarzając gesty i słowa Jezusa z Ostatniej Wieczerzy" (Jan Paweł II, Listy na Wielki Czwartek, 28.03.2004, nr 2, 318). 
im mandat nauczania wszystkich narodów (pot. Mt 28, 19) oraz kształcenia i kierowania kapłańskim ludem. Misja Apostołów, którą Pan Jezus stale powierza pasterzom swojego ludu, jest prawdziwą służbą, która w Piśmie Świętym określona jest znamiennym mianem "diakonii", czyli posługi, urzędu. W nieprzerwanie trwającej sukcesji apostolskiej kapłani w chwili święceń otrzymują od Zmartwychwstałego Chrystusa charyzmat Ducha Świętego a wraz z nim - władzę i świętą moc działania in persona Christi Capitis (w zastępstwie Chrystusa Głowy), ażeby głosząc Ewangelię i sprawując sakramenty służyli Kościołowi i jednoczyli go w Duchu Świętym ${ }^{8}$.

Należy zatem powiązać istotową różnicę między kapłaństwem służebnym a kapłaństwem powszechnym z sukcesją apostolską, która z kolei jest jedynym uprawnieniem do sprawowania ważnie sakramentu Eucharystii czy też udzielenia sakramentalnego rozgrzeszenia. W tych sakramentach szczególnie kapłan działa in persona Christi. Powiązanie to wskazuje, że różnica między kapłaństwem służebnym a kapłaństwem powszechnym jest bardzo wyraźna. Dla potwierdzenia tej tezy, można posłużyć się dokumentem Kongregacji Nauki Wiary, która już w 1983 roku wystosowała list Sacerdotium ministeriale, aby dokładniej wyjaśnić, że owa różnica „istoty”, a nie tylko „stopnia” oznacza, że tylko biskupi i prezbiterzy mają władzę sprawowania misterium Eucharystii. Ta święta władza jest ściśle związana ze święceniami sakramentalnymi przynajmniej w stopniu prezbitera. Tylko kapłani bowiem mają władzę i przywilej działać in persona Christi, a przez to między innymi konsekrować chleb i wino podczas Eucharystii, by stały się Ciałem i Krwią Chrystusa, czy też w Jego imię odpuszczać grzechy lub namaszczać chorych. Odrzucanie takiego nauczania sprzeciwia się przekazywanej od wieków wierze, ponieważ „nie tylko odrzuca władzę powierzoną kapłanom, ale narusza całą strukturę apostolską Kościoła oraz deformuje sakramentalną strukturę zbawienia" ${ }^{\text {. }}$

8 Jan Paweł II, Adhortacja apostolska Christifideles laici, 30.12.1988, 22, http://www.vatican.va/content/john-paul-ii/pl/apost_exhortations/documents/hf_jp-ii_exh_30121988_ christifideles-laici.html (16.02.2021).

9 Kongregacja Nauki Wiary, Sacerdotium ministeriale, III/1, http://www.vatican.va/roman_curia/congregations/cfaith/documents/rc_con_cfaith_doc_19830806_sacerdotium-ministeriale_pl.html (16.02.2021). 
Ze względu na tę istotną różnicę, w Katechizmie Kościoła katolickiego już w pierwszej wersji numeru 875 mogliśmy przeczytać o tym, że:

Nikt nie może sam siebie upoważnić do głoszenia Ewangelii. Posłany przez Pana mówi i działa nie przez swój własny autorytet, ale na mocy autorytetu Chrystusa; nie jako członek wspólnoty, ale mówiący do niej w imieniu Chrystusa. Nikt nie może sam sobie udzielić łaski, ale musi być ona dana i ofiarowana. Zakłada to szafarzy (ministri) łaski, upoważnionych i uzdolnionych przez Chrystusa. Od Niego otrzymują oni „świętą władzę” działania in persona Christi Capitis. Władzę, dzięki której posłani przez Chrystusa czynią i dają na mocy daru Bożego to, czego nie mogą czynić i dawać sami z siebie, tradycja Kościoła nazywa „sakramentem”. Ta władza przekazywana w Kościele za pośrednictwem osobnego sakramentu ${ }^{10}$.

Podobne kwestie znajdują się w normie kodeksowej o charakterze doktrynalnym, dotyczącej sakramentu święceń:

\begin{abstract}
Na mocy ustanowienia Bożego, przez sakrament kapłaństwa niektórzy spośród wiernych, naznaczeni w nim niezatartym charakterem, są ustanawiani świętymi szafarzami; są oni mianowicie konsekrowani i przeznaczeni ażeby - każdy odpowiednio do swojego stopnia, wypełniając w osobie Chrystusa-Głowy zadania nauczania, uświęcania i kierowania - byli pasterzami Ludu Bożego (kan. 1008 KPK).
\end{abstract}

A zatem, jak podkreśla zarówno kodeks, jak i katechizm, to z sakramentu święceń wypływa ta szczególna władza działania w imieniu Chrystusa. Ponadto w tych dwóch tekstach można zauważyć również subtelnie wskazaną różnicę, która wymaga teologicznego pogłębienia, a mianowicie działania in persona Christi oraz nomine Christi. W kilku dokumentach to rozróżnienie jest obecne, jednak zostało przedstawione bardzo subtelnie, tak jakby ta kwestia jeszcze wymagała bardziej zawansowanej teologicznej argumentacji ${ }^{11}$. Należy stwierdzić, że działanie

10 Katechizm Kościoła katolickiego, Poznań 1994, nr 875 [dalej: KKK]. Celowo zacytowaliśmy fragment z pierwszego wydania, aby później nawiązać do wprowadzonej zmiany wynikającej z pogłębionej refleksji dotyczącej diakonów.

11 W Pastores dabo vobis w numerze 15, Jan Paweł II napisał: „Prezbiterzy są w Kościele i dla Kościoła sakramentalnym uobecnieniem Jezusa Chrystusa Głowy i Pasterza, głoszą autorytatywnie Jego słowo, powtarzają Jego znaki przebaczenia i daru zbawienia, zwłaszcza w sakramencie chrztu, pokuty oraz w Eucharystii, dzielą Jego pełną miłości troskę aż do całkowitego złożenia daru z siebie za owczarnię, którą gromadzą w jedno i prowadzą do Ojca przez Chrystusa w Duchu Świętym. Jednym słowem, celem życia i działania kapłanów jest 
in persona Christi odnosi się do czynności sakramentalnych wypełnianych przez kapłana (w szczególności chodzi o Eucharystię i sakrament pokuty), ponieważ w nich Chrystus działa ex opere operato. Natomiast działanie nomine Christi odnosi się do działania w sakramentaliach, w nauczaniu oraz aktach władzy rządzenia ${ }^{12}$.

\section{Różnica w misji i władzy święceń kapłanów, a w posłudze diakonów}

Pogłębiona refleksja nad nauczaniem ostatniego soboru powszechnego w kwestii diakonów doprowadziła do istotnego przeformułowania w pierwszej kolejności Katechizmu Kościoła katolickiego. Decyzję w tej kwestii podjął jeszcze Jan Paweł II. Zmiana została dokonana w cytowanym już numerze $875 \mathrm{KKK}^{13}$ : „Od Niego biskupi i prezbiterzy, otrzymują misję i «świętą władzę» działania in persona Christi Capitis”. Powody tej zmiany oraz późniejsze zmiany w KPK wyjaśnia papież Benedykt XVI w motu proprio Omnium in mentem z 2009 roku:

Przede wszystkim, w kanonach 1008 i 1009 Kodeksu prawa kanonicznego, dotyczących sakramentu święceń, potwierdza się zasadnicze rozróżnienie powszechnego kapłaństwa wiernych i kapłaństwa służebnego i jednocześnie podkreśla się, że istnieje różnica między biskupstwem, prezbiteratem i diakonatem. Nasz czcigodny poprzednik Jan Paweł II postanowił, po konsultacjach z Ojcami Kongregacji Nauki Wiary, że trzeba zmienić tekst oznaczony numerem $875^{*}$ Katechizmu Kościoła katolickiego, aby lepiej wyrazić naukę o diakonach, zawartą w Konstytucji dogmatycznej Lumen gentium (n. 29) Soboru Watykańskiego II. My także uważamy,

głoszenie Ewangelii światu i budowanie Kościoła w imieniu i w zastępstwie Chrystusa (in persona Christi), Głowy i Pasterza". A także w numerze 10 Pastores gregis takie rozróżnienie zostało podkreślone przez tego samego papieża: „Będąc darem Ducha Świętego dla Kościoła, biskup jest przede wszystkim i jak każdy inny chrześcijanin synem i członkiem Kościoła. Od tej Świętej Matki otrzymał dar życia Bożego w sakramencie Chrztu i pierwsze pouczenie $\mathrm{w}$ wierze. Wraz ze wszystkimi innymi wiernymi dzieli on wyjątkową godność dziecka Bożego, którą ma przeżywać w komunii i w duchu wdzięcznego braterstwa. Z drugiej strony, na mocy pełni sakramentu Święceń, biskup jest także tym, który wobec wiernych jest nauczycielem, uświęcającym i pasterzem, któremu powierzono działanie w imię i w osobie chrystusa".

12 Por. G. Ghirlanda, Il Sacramento dell'ordine e la vita dei chierici, 24.

13 Zamiast wcześniejszego słowa „oni” zostało wyszczególnione, że chodzi o biskupów i prezbiterów, oraz dodane zostało, że oni otrzymują misję i „świętą władzę”. 
że trzeba udoskonalić dotyczącą tej kwestii normę kanoniczną. Po zasięgnięciu opinii Papieskiej Rady ds. Tekstów Prawnych postanawiamy zatem, że słowa wspomnianych kanonów będą zmienione, jak wskazuje się poniżej ${ }^{14}$.

Od momentu wejścia w życie motu proprio, kan. 1008 KPK brzmi w następujący sposób:

Na mocy ustanowienia Bożego, przez sakrament kapłaństwa niektórzy spośród wiernych, naznaczeni w nim niezatartym charakterem, są ustanawiani świętymi szafarzami; są oni mianowicie konsekrowani i przeznaczeni, ażeby - każdy odpowiednio do swojego stopnia - służyć Ludowi Bożemu z nowego i szczególnego tytułu ${ }^{15}$.

\section{Z kolei do kan. 1009 KPK wprowadzono trzeci paragraf:}

Ci, którzy zostali ustanowieni biskupami lub prezbiterami, otrzymują misję i władzę działania w osobie Chrystusa-Głowy, natomiast diakoni zostają ustanowieni po to, by służyli ludowi Bożemu poprzez diakonię liturgii, słowa i miłości (kan. 1009 §3 KPK).

Zmiana wprowadzona przez motu proprio Benedykta XVI, dotycząca Kodeksu prawa kanonicznego, jest zatem do odczytania w tym kluczu lepszego wyrażenia nauki o diakonach z jednoczesnym potwierdzeniem zasadniczego rozróżnienia kapłaństwa powszechnego i kapłaństwa ministerialnego. Nie jest zatem wystarczające twierdzenie, że zmiana miała na celu lepsze oddanie uporządkowanego opisu kapłaństwa hierarchicznego przekazanego w nauczaniu ojców soborowych w Lumen gentium ${ }^{16}$. Oczywiście zmiana, jak podkreśla papież Benedykt XVI, jest spowodowana pogłębioną refleksją na temat diakonatu, ale nie chodzi tutaj tylko o sam fakt, że ten stopień święceń przez lata był postrzegany jako etap na drodze do prezbiteratu, wypaczając w ten sposób jego pierwotną

14 Benedykt XVI, m.p. Omnium in mentem, 26.10.2009, https://opoka.org.pl/biblioteka/ W/WP/benedykt_xvi/motu/omnium_26102009.html (13.02.2021). *numer w tłumaczeniu jest błędny, dlatego został poprawiony na właściwy, por. AAS 102 (2010) 8.

15 Został usunięty fragment: „wypełniając w osobie Chrystusa-Głowy zadania nauczania, uświęcania i kierowania - byli pasterzami Ludu Bożego" i zastąpiony ostatnim sformułowanie obecnie obowiązującego kanonu.

16 Por. LG 18-29. 
rolę w Kościele. Na podstawie dokonanych zmian ciężko jest dojść też do wniosku, że jest to przypomnienie o odnowieniu diakonatu stałego i postawienie go we właściwej roli, którą jest posługa liturgii, słowa i miłości. W dokonanej zmianie, czytając łącznie kan. 1008 i 1009 KPK, należy zauważyć intencję Prawodawcy.

Papież Benedykt XVI, wyłączając z pierwszego kanonu działanie na mocy święceń in persona Christi, a wprowadzając do kan. 1009 KPK paragraf o diakonach w odróżnieniu od kapłanów, pozwala zrozumieć, że intencją tej zmiany było podkreślenie, że tylko kapłani (biskupi i prezbiterzy), nie zaś diakoni, działają in persona Christi.

To kapłani sprawują sakramenty in persona Christi, w których jest szczególne działanie Chrystusa ex opere operato, do których z ustanowienia Bożego jest wymagana władza święceń (szczególnie Eucharystia i pokuta, ale także namaszczenie chorych). A zatem zmiany w obydwu kanonach były powodowane przede wszystkim potrzebą usunięcia nieścisłości związanej z tym, że w poprzednim brzmieniu kanonów kodeksu można było wyciągnąć wniosek, że diakon również działa w osobie Chrystusa-Głowy, a to jest niezgodne z nauczaniem Kościoła. Podkreślenie służebnego charakteru posługi diakona jest, w mojej ocenie, wyjaśnieniem drugorzędnym. Istotą jest stwierdzenie, że w misji i „władzy świętej" uczestniczą tylko biskupi i prezbiterzy, nie zaś diakoni ${ }^{17}$.

\section{Różnice między poszczególnymi stopniami święceń}

Wprowadzenie zmian przez motu proprio Benedykta XVI wpływa na lepsze zrozumienie różnicy między pierwszym stopniem święceń (diakonatem) a pozostałymi dwoma (prezbiteratem i episkopatem). Jednak w świetle nauczania soborowego należy przeanalizować specyfikę poszczególnych stopni, celem lepszego zrozumienia sakramentu święceń i jego trzech stopni. Zgodnie z kolejnością przyjmowania stopni święceń, a zatem w odwrotnej kolejności niż to jest w soborowej Konstytucji dogmatycznej o Kościele, przedstawimy poszczególne stopnie i zasadniczą

17 Por. P. Wojnarowicz, Sakrament święceń i małżeństwa według motu proprio „Omnium in mentem” Benedykta XVI, „Kościół i Prawo” 3 (2014) nr 1, s. 113-114. 
ich charakterystykę. Pozwoli to na jeszcze wyraźniejsze podkreślenie różnicy między diakonatem a pozostałymi stopniami (o czym już wspomniano powyżej), ale także na analizę różnicy między prezbiteratem a episkopatem.

\subsection{Ustanowienie Boże oraz łaska sakramentalna poszczególnych stopni}

Zanim zostaną przedstawione różnice stopni pozwalające zrozumieć wyszczególnienie każdego ze stopni święceń, należałoby po krótce przedstawić również wspólne aspekty, które potwierdzają, iż jest to jeden sakrament $\mathrm{w}$ trzech stopniach. Na podkreślenie zasługuje w pierwszej kolejności ustanowienie wszystkich trzech stopni, a także łaska związana $\mathrm{z}$ otrzymaniem poszczególnych stopni tego sakramentu. Jednak prowadzenie rozważań na temat sakramentalności poszczególnych trzech stopni już na samym początku tej części artykułu byłoby bardzo trudne. Teoretycznie są to kwestie, które powinny być wspólne dla wszystkich trzech stopni, jednak głębsza analiza aspektów teologicznych, prawnych i historycznych pokazuje, że również w tych kwestiach pojawiają się rozbieżności wśród uczonych. Dlatego refleksja na temat sakramentalności zostanie podjęta przy okazji rozważania poszczególnych stopni.

Co zaś dotyczy kwestii ustanowienia stopni sakramentu święceń, w pierwszej kolejności zaczerpniemy z nauczania ostatniego Soboru, który w tej materii stwierdził:

tak oto urząd kościelny, przez Boga ustanowiony, sprawowany jest w różnych stopniach święceń przez tych, którzy od starożytności już noszą nazwę biskupów, prezbiterów i diakonów ${ }^{18}$.

W tej materii ojcowie soborowi inspirowali się nauczaniem Soboru Trydenckiego ${ }^{19}$. Nie mówią oni o Bożym ustanowieniu (divina institutione),

\footnotetext{
18 LG 28.

19 „Ponieważ posługa tak świętego kapłaństwa jest rzeczą Bożą, czymś naturalnym było - by godniej i z większą czcią mogło być sprawowane - by w uporządkowanej strukturze Kościoła istniało kilka różnych święceń szafarzy, które z urzędu służyłyby kapłaństwu, tak podzielonych, by posiadający już tonsurę duchownych od niższych wstępowali na wyższe. Księgi Pisma Świętego wyraźnie wzmiankują nie tylko o kapłanach, ale również o diakonach,
} 
ale o Bożym rozporządzeniu (divina ordinatione). To wskazuje, że nie było zamysłem ojców Soboru Trydenckiego stwierdzenie, że wszystkie stopnie są z ustanowienia Bożego, ponieważ brano pod uwagę również niższe stopnie, dlatego kwestia diakonatu pozostała nierozstrzygnięta ${ }^{20}$. Podobnie tekst Lumen gentium nie mówi nic na temat natury trzech stopni ani o tym, czy podział między nimi jest z ustanowienia Bożego czy też nie ${ }^{21}$.

\subsection{Pierwszy stopień święceń - diakonat}

Ponieważ kwestia sakramentalności poszczególnych stopni od wieków była dyskutowana i nadal nie została do końca rozstrzygnięta, zgodnie z nauczaniem Konstytucji dogmatycznej o Kościele diakoni są ,umocnieni bowiem łaską sakramentalną, w posłudze liturgii, słowa i miłości służą Ludowi Bożemu w łączności z biskupem i jego kapłanami" 22 . Sobór nie mówi wprost o sakramentalności diakonatu, a jedynie o łasce sakramentalnej. Można powiedzieć, że ten sakramentalny charakter diakonatu zaznacza się z pewną ostrożnością. Z jednej strony przecież jest on ugruntowany w tradycji i nauczaniu, z drugiej Vaticanum II nie chciał sprawiać wrażenia potępienia niektórych autorów, którzy poddają w wątpliwość sakramentalność diakonatu ${ }^{23}$. To, co Sobór pozostawił bez rozstrzygnięcia doktrynalnego, jeszcze bardziej prowokuje do rozważań na ten temat, aby pogłębić kierunki wyznaczone przez stwierdzenia soborowe.

W tej sytuacji należałoby stwierdzić, że pogłębiona refleksja, dokonana zarówno przez papieża Jana Pawła II, jak i ojców Kongregacji Nauki Wiary, doprowadziła następcę Piotra do wniosku, iż należy dokonać

i w stanowczych słowach uczą tego, na co szczególnie należy uważać przy ich święceniu" Sobór Trydencki, Prawdziwa i katolicka nauka o sakramencie święceń dla potępienia błędów naszych czasów, rozdział 2: O siedmiu święceniach, [a-b], red. A. Baron, H. Pietras, Kraków 2005, s. 681 (Dokumenty Soborów Powszechnych [dalej: DSP], 4/2).

A także w innym miejscu: „Gdyby ktoś mówił, że w Kościele katolickim nie ma hierarchii, ustanowionej z Bożego rozporządzenia, która obejmuje biskupów, prezbiterów oraz [innych] szafarzy - niech będzie wyklęty" - Sobór Trydencki, Kanony o sakramencie święceń, red. A. Baron, H. Pietras, Kraków 2005, s. 685 (DSP 4/2).

20 Por. G. Ghirlanda, Il Sacramento dell'ordine e la vita dei chierici, 33-34.

21 Por. G. Ghirlanda, Il Sacramento dell'ordine e la vita dei chierici, 46.

22 LG 29.

23 por. G. Ghirlanda, Il Sacramento dell'ordine e la vita dei chierici, 48. 
korekty w KKK. Podobnie jak w przypadku papieża Benedykta XVI, który zauważył, że teologia sakramentu święceń domaga się, aby w kodeksie prawa kanonicznego zmieniono treść dwóch kanonów. W kwestii diakonatu zostały - na podstawie Lumen gentium - wprowadzone zapisy wyraźnie odróżniające posługę diakonów od pozostałych dwóch stopni biskupa i prezbitera, którzy otrzymują „misję i władzę działania w osobie Chrystusa-Głowy", natomiast diakoni zostają ustanowieni do posługi Ludowi Bożemu (por. kan. 1009 §3 KPK). W tym paragrafie zostało zawarte to, co już Sobór określił w stwierdzeniu, że „na niższym szczeblu hierarchii stoją diakoni, na których nakłada się ręce «nie dla kapłaństwa, lecz dla posługi»"24. Powstaje zatem teologiczno-prawny dylemat: do jakiego stanu należą diakoni oraz czy ich posługa jest posługą wynikającą z kapłaństwa ministerialnego, hierarchicznego, zwanego też służebnym, czy też wynika z kapłaństwa powszechnego. Skoro Sobór wyraźnie stwierdza, posługując się starożytnymi konstytucjami, że nałożenie rąk przy święceniach diakonatu nie jest dla kapłaństwa, to należałoby stwierdzić, że jest to nadal posługa wynikająca z kapłaństwa powszechnego. Tym bardziej, że analizując uprawnienia diakonów w przypadku uświęcającego zadania Kościoła, nie otrzymują oni specjalnych uprawnień w stosunku do wiernych świeckich w przypadku szafowania sakramentów, a jedynie specjalny tytuł - wynikający właśnie z przyjętych święceń. W kategoriach prawnych diakoni zostają zaliczeni do duchowieństwa w momencie przyjęcia święceń i zostają inkardynowani do Kościoła partykularnego lub prałatury personalnej (por. kan. 266 \$1 KPK). Jednakże w kwestii określenia, czy posługa diakona jest to realizacja kapłaństwa powszechnego czy też kapłaństwa ministerialnego, mimo pogłębionego studium biblijnego, historycznego, prawnego, teologicznego Międzynarodowa Komisja Teologiczna nie zdecydowała się zaproponować rozwiązania ${ }^{25}$.

24 LG 29.

25 Międzynarodowa Komisja Teologiczna, Il diaconato: evoluzione e prospettive, 30.09.2002, http://www.vatican.va/roman_curia/congregations/cfaith/cti_documents/rc_con_cfaith_ pro_05072004_diaconate_it.html\#_ftn* (15.02.2021). 


\subsection{Drugi stopień święceń - prezbiterat}

W soborowym Dekrecie o posłudze i życiu prezbiterów Presbyterorum ordinis możemy przeczytać, że

kapłaństwo prezbiterów zakłada wprawdzie sakramenty chrześcijańskiego wtajemniczenia, zostaje jednak udzielone przez ten specjalny sakrament, mocą którego prezbiterzy, dzięki namaszczeniu Ducha Świętego, zostają naznaczeni szczególnym znamieniem i tak upodabniają się do Chrystusa Kapłana, aby mogli działać w zastępstwie Chrystusa Głowy ${ }^{26}$.

Podkreśla to, że sakrament święceń drugiego stopnia nadaje szczególny charakter osobie, która go przyjęła. Mianowicie otrzymuje misję i władzę świętą działania w imieniu Chrystusa. Prezbiter, otrzymując święcenia, staje się kapłanem, ponieważ otrzymuje sukcesję apostolską, która będąc charyzmatem otrzymywanym w widzialnej wspólnocie Kościoła i jest tym

aspektem natury i życia Kościoła, który pokazuje aktualną zależność wspólnoty od Chrystusa, która urzeczywistnia się za pośrednictwem zależności od tych, których On posłał ${ }^{27}$.

W ten sposób uczestnicząc w tej misji, którą sami apostołowie otrzymali od Chrystusa, prezbiterzy mają władzę sprawowania Najświętszej Eucharystii (por. kan. 900 §1 KPK), władzę odpuszczania grzechów (por. kan. $965 \mathrm{KPK})$, czy też udziela sakramentu namaszczenia chorych (por. kan. 1003 \$1 KPK). Sukcesja apostolska jest tym gwarantem, który daje władzę sprawowania sakramentów ważnie ${ }^{28}$.

26 PO 2.

27 Międzynarodowa Komisja Teologiczna, Apostolskość Kościoła i sukcesja apostolska, 1973, http://www.vatican.va/roman_curia/congregations/cfaith/cti_documents/rc_cti_1973_ successione-apostolica_pl.html\#_ednref1 (15.02.2021).

${ }_{28}$ W rzeczywistości posiadanie sukcesji apostolskiej ma bardzo ważny wymiar w kwestiach ekumenicznych i postrzegania innych Kościołów i wspólnot kościelnych. Owo powiązanie sukcesji apostolskiej i Eucharystii podkreśla Deklaracja Dominus Iesus: „Kościoły, które nie będąc w pełnej wspólnocie z Kościołem katolickim, pozostają jednak z nim zjednoczone bardzo ścisłymi więzami, jak sukcesja apostolska i ważna Eucharystia, są prawdziwymi Kościołami partykularnymi. Dlatego także w tych Kościołach jest obecny i działa Kościół Chrystusowy, chociaż brak im pełnej komunii z Kościołem katolickim, jako że nie uznają 
Jednak prezbiterzy uczestniczą $\mathrm{w}$ odpowiedniej mierze w urzędzie apostołów, ponieważ obwiązek posługi biskupiej został zlecony prezbiterom w stopniu podporządkowanym ${ }^{29}$.

\subsection{Trzeci stopień święceń - episkopat}

Sobór Watykański poucza, że „w osobach biskupów, których pomocnikami są kapłani (łac. presbyteri), obecny jest wśród wiernych Pan Jezus Chrystus, Kapłan Najwyższy"30. Można zatem zauważyć, że na mocy święceń biskupich i poprzez hierarchiczną komunię z Głową oraz członkami Kolegium elekt zostaje ustanowiony członkiem stanu biskupiego. Ten zaś z kolei przejmuje po kolegium apostołów zadania w dziedzinie nauczania i pasterskiego kierownictwa. Przez tych, którzy przez apostołów zostali ustanowieni biskupami oraz ich następców jest przekazywana i zachowywana tradycja apostolska - jak głosi św. Ireneusz ${ }^{31}$.

Powstaje jednak uzasadnione pytanie, czy konsekracja biskupia ma charakter sakramentalny czy też nie. Aby odpowiedzieć na to pytanie należy pochylić się nad różnicami między prezbiteratem a biskupstwem. Wśród ojców i doktorów Kościoła widoczne były różnice w tej kwestii. Jedni - jak św. Hieronim ${ }^{32}$ - uważali, że podział na biskupów i prezbiterów został wprowadzony z powodów dyscypliny kościelnej wymuszonej przez pojawiające się herezje i schizmy. Potwierdza to swoistego rodzaju jedność między władzą świętą biskupa i prezbitera. Innego zdania był Dionizy Areopagita (PseudoDionizy) ${ }^{33}$, który twierdził, że wszystko co istnieje, jest stworzone w sposób hierarchiczny w porządku triadycznym,

katolickiej nauki o prymacie, który Biskup Rzymu posiada obiektywnie z ustanowienia Bożego i sprawuje nad całym Kościołem.

Natomiast wspólnoty kościelne, które nie zachowały prawomocnego Episkopatu oraz właściwej i całkowitej rzeczywistości eucharystycznego misterium, nie są Kościołami w ścisłym sensie; jednak ochrzczeni w tych Wspólnotach są przez chrzest wszczepieni w Chrystusa i dlatego są w pewnej wspólnocie, choć niedoskonałej, z Kościołem” (nr 17).

29 Por. PO 2.

30 LG 21.

31 Por. LG 20.

32 Zob. Św. Hieronim ze Strydonu, Listy, t. 5, list 146, 2.

33 Zob. Dionysius the Pseudo-Aeropagite, The Ecclesiastical Hierarchy, w: L.J. Johnson, An Anthology of Historical Sources, Philadelphia 2009, s. 213 (Worship in the early Church, 4). 
a przez to również biskupi, prezbiterzy i inni szafarze są z ustanowienia Bożego. W konsekwencji także różnica między prezbiteratem a biskupstwem jest z takiego ustanowienia. W drugim millenium Gracjan i pierwsi dekretaliści - Piotr Lombard, św. Bonawentura, św. Albert Wielki oraz św. Tomasz z Akwinu, analizując zagadnienie, dochodzili do innych wniosków, odmiennych niż Areopagita, opowiadając się zatem za uzasadnieniem św. Hieronima. Wskazane jest przytoczyć argumentację św. Tomasza z Akwinu, która może być określona podsumowaniem rozważań wszystkich tych autorów ${ }^{34}$ :

Otóż św. Tomasz stwierdza, że episkopat nie jest nowym rodzajem święcenia w relacji do prezbiteratu, ponieważ nie daje biskupowi tego, czego by nie posiadał prezbiter, w perspektywie prawdziwego Ciała Chrystusa, Eucharystii, który jest najwyższym z sakramentów. Owszem w stosunku do niektórych sakramentów daje pewną władzę, jednak nie można powiedzieć, że daje większą władzę co do tej posiadanej przez prezbiterów. Najistotniejszym jest to, że daje możliwość oddziaływania na Ciało Mistyczne - Kościół, a zatem różnica jest w tym, że biskup posiada władzę rządzenia w Ciele Mistycznym, a to daje mu pewne zarezerwowane czynności sakramentalne (bierzmowanie i święcenia) oraz sprawowanie niektórych sakramentaliów (wybrane błogosławieństwa). W tym sensie biskup nie ma tylko władzy rządzenia, ale także pewną władzę święceń, którą realizuje w odróżnieniu od prezbitera ${ }^{35}$.

Można stwierdzić, że konsekracja biskupia czyni elekta zdolnym do wykonywania w pełni tego, co otrzymał w sakramencie święceń kapłańskich już w stopniu prezbiteratu. I tak, pod koniec średniowiecza, między kanonistami trwało przekonanie o sakramentalnym charakterze stopnia święceń biskupich, a wśród teologów było zupełnie odwrotnie, ponieważ twierdzili, że różnica między stopniem biskupa a stopniem prezbitera jest tylko z prawa kościelnego ${ }^{36}$. Co ciekawe Sobór Trydencki nie podjął bezpośrednio tego problemu, a jedynie w niektórych

34 Por. Sent. IV, d. 7, q. 3, a. 1, q.la 2, ad 3um; d. 24, q. 3, a. 2, q.la 2, sol., https://www. corpusthomisticum.org/snp4007.html (16.02.2021) oraz https://www.corpusthomisticum. org/snp4024.html (16.02.2021).

35 Por. G. Ghirlanda, Il Sacramento dell'ordine e la vita dei chierici, 35.

36 Por. G. Ghirlanda, Il Sacramento dell'ordine e la vita dei chierici, 35. 
wypowiedziach poruszył to zagadnienie ${ }^{37}$. Na Soborze Trydenckim nie było zamiaru rozstrzygnięcia tej kwestii, jednak brak przez dłuższy czas publikacji tekstów sprawił, że również wśród teologów ugruntowała się opinia o sakramentalności święceń biskupich ${ }^{38}$. Na Soborze Watykańskim II natomiast sakramentalność święceń biskupich zmieniała swoją perspektywę od tej ugruntowanej na przekonaniu o wyższości stopnia władzy święceń, do tej odnoszącej się bardziej do sukcesji apostolskiej, a przez to do władzy nauczania i rządzenia i w konsekwencji przynależności do stanu biskupiego. Takie też stwierdzenia zawiera obecny wstęp do obrzędów święceń biskupich, reasumujący nauczanie Soboru Watykańskiego II ${ }^{39}$.

\section{Podsumowanie}

Podjęta w artykule próba przedstawienia różnic między kapłaństwem powszechnym a kapłaństwem służebnym oraz między poszczególnymi stopniami święceń pozwala na sformułowanie stwierdzenia, że w tej materii jest to dopiero początek refleksji teologicznej oraz prawnej. Ingerencja Benedykta XVI w brzmienie kanonów dotyczących sakramentu święceń była i jest okazją do tego, aby nadal zgłębiać te zagadnienia.

W przypadku różnic między kapłaństwem powszechnym, a kapłaństwem służebnym można pokusić się o hipotezę, o której pisał ks. Strzelczyk, opierając się na kategorii relacji. Widać w niej różnicę relacji do Chrystusa (i przez Niego do Ojca oraz do Ducha Świętego). Na mocy sakramentu chrztu rodzi się relacja podobieństwa (tożsamości)

37 „Gdyby ktoś mówił, że biskupi nie są wyżsi od prezbiterów, albo że nie mają władzy bierzmowania i udzielania święceń, albo że ta, którą mają, jest im wspólna z prezbiterami; albo że święcenia przez nich udzielone bez zgody lub powołania ze strony ludu lub władzy świeckiej są nieważne; albo że ci którzy nie zostali ważnie wyświęceni i posłani przez władzę kościelną i kanoniczną, ale przychodzą skądinąd, są prawomocnymi sługami słowa i sakramentów - niech będzie wyklęty" (Sobór Trydencki, Kanony o sakramencie święceń, 7, red. A. Baron, H. Pietras, Kraków 2005, s. 685-687 [DSP 4/2]).

38 por. G. Ghirlanda, Il Sacramento dell'ordine e la vita dei chierici, 36.

39 Por. Wprowadzenie ogólne, w: Obrzęd święceń biskupa, prezbiterów i diakonów, 12, wyd. 2. popr., Kraków 2019. 
do Chrystusa oddającego się Ojcu, na mocy sakramentu święceń powstaje relacja do Chrystusa gromadzącego Kościół ${ }^{40}$.

W bardziej prawniczej optyce będzie to z pewnością kategoria sukcesji apostolskiej, dzięki której kapłaństwo służebne ma władzę świętą konsekrować chleb i wino, aby stały się Ciałem i Krwią Chrystusa, a zatem tylko kapłaństwo służebne może składać ofiarę eucharystyczną. Wszyscy zaś wierni, na mocy chrztu, są wezwani do tego, aby uczestniczyć w kapłańskim zadaniu Chrystusa i składać swoje życie w ofierze Bogu ${ }^{41}$.

To zaś skłania nas do tego, aby przedstawić - w formie tezy - kwestię diakonów, która była motywem interwencji dwóch papieży w treści katechizmu oraz kodeksu. Należałoby zastanowić się, nad pewną analogią do statusu osób konsekrowanych (por. kan. 207 \2 KPK) i w ten sposób popatrzeć na diakonów, którzy z jednej strony nie należą do kapłaństwa służebnego, ponieważ nakładane na nich ręce są „dla służby, a nie dla kapłaństwa", przez co należy stwierdzić, że wszystko co robią, wpisuje się w realizację kapłaństwa powszechnego. Z drugiej strony otrzymali już pierwszy stopień święceń, a przez to otrzymali łaskę sakramentalną do realizowania owej służby. Dlatego też to oni są pierwszymi spośród wiernych, którzy powinni owe zadania realizować, np. udzielać chrztu czy rozdawać komunię świętą jako szafarze zwyczajni. Można tę tezę uznać również za zauważenie pewnego teologiczno-prawnego problemu, który nadal jest zawarty w kodeksie prawa kanonicznego, a mianowicie diakoni są duchownymi, a kan. 207 \$1 KPK stawia między szafarzami i duchownymi znak równości. To, co w kan. 1009 KPK po jego zmianie zostało wyjaśnione, iż diakoni nie są kapłanami, pozostaje jeszcze w podziale na szafarzy (duchownych) i świeckich, wraz ze stwierdzeniem, że jest to „z ustanowienia Bożego” (kan. 207 §1 KPK). Stąd też nasza teza pewnego umiejscowienia diakonów w szczególnej pozycji, poza szafarzami świętymi oraz świeckimi, przez analogię do osób konsekrowanych. Diakon to ten, który należy do duchownych, ale realizuje swoje zadania na podstawie kapłaństwa powszechnego.

40 Por. G. Strzelczyk, „Istotą, a nie tylko stopniem” (LG 10). Hipoteza wyjaśnienia, „Śląskie Studia Historyczno-Teologiczne" 44 (2011) z. 1, s. 134.

${ }^{41}$ Por. KKK 2100. 


\section{Bibliografia}

Benedykt XVI, List apostolski motu proprio Omnium in mentem, 26.10.2009, https://opoka.org.pl/biblioteka/W/WP/benedykt_xvi/motu/omnium_26102009. html (13.02.2021).

Codex Iuris Canonici auctoritate Joannis Pauli PP. II promulgatus, 25.01.1983, „Acta Apostolicae Sedis" 75 (1983), pars 2, s. 1-317; tekst polski: Kodeks prawa kanonicznego, przekład polski zatwierdzony przez Konferencję Episkopatu Polski, Poznań 1984.

Dionyzy Pseudo-Aeropagita, The Ecclesiastical Hierarchy, w: L.J. Johnson, An Anthology of Historical Sources, Philadelphia 2009, s. 201-219 (Worship in the early Church, 4).

Ghirlanda G., Il Sacramento dell'ordine e la vita dei chierici, Roma 2019.

Jan Paweł II, List na Wielki Czwartek, 24.02.1980, w: Listy na Wielki Czwartek 1979-2005, red. K. Lubowicki, Kraków 2005, s. 35-64.

Jan Paweł II, List na Wielki Czwartek, 28.03.2004, w: Listy na Wielki Czwartek 19792005, red. K. Lubowicki, Kraków 2005, s. 317-323.

Jan Paweł II, Adhortacja apostolska Christifideles laici, 30.12.1988, http://www. vatican.va/content/john-paul-ii/pl/apost_exhortations/documents/hf_jp-ii_ exh_30121988_christifideles-laici.html (16.02.2021).

Jan Paweł II, Adhortacja apostolska Pastores dabo vobis, 25.03.1992, http://www. vatican.va/content/john-paul-ii/pl/apost_exhortations/documents/hf_jp-ii_ exh_25031992_pastores-dabo-vobis.html (16.02.2021).

Jan Paweł II, Adhortacja apostolska Pastores gregis, 16.10.2003, http://www.vatican. va/content/john-paul-ii/pl/apost_exhortations/documents/hf_jp-ii_exh_20031016_ pastores-gregis.html (16.02.2021).

Katechizm Kościoła katolickiego, Poznań 1994.

Kongregacja Nauki Wiary, Deklaracja Dominus Iesus, 6.08.2000, https://opoka.org. pl/biblioteka/W/WR/kongregacje/kdwiary/dominus_iesus.html (16.02.2021).

Kongregacja Nauki Wiary, List do biskupów kościoła katolickiego o niektórych zagadnieniach dotyczących szafarza Eucharystii Sacerdotium ministeriale, III/1, http:// www.vatican.va/roman_curia/congregations/cfaith/documents/rc_con_cfaith_ doc_19830806_sacerdotium-ministeriale_pl.html (16.02.2021).

Międzynarodowa Komisja Teologiczna, Apostolskość Kościoła i sukcesja apostolska, 1973, http://www.vatican.va/roman_curia/congregations/cfaith/cti_documents/ rc_cti_1973_successione-apostolica_pl.html\#_ednref1 (15.02.2021).

Międzynarodowa Komisja Teologiczna, Il diaconato: evoluzione e prospettive, 30.09.2002, http://www.vatican.va/roman_curia/congregations/cfaith/cti_documents/rc_con_cfaith_pro_05072004_diaconate_it.html\#_ftn* (15.02.2021).

Obrzędy święceń biskupa, prezbiterów i diakonów, wyd. 2. popr., Katowice 2019.

Sobór Trydencki, Kanony o sakramencie święceń, red. A. Baron, H. Pietras, Kraków 2007 (DSP 4/2).

Sobór Trydencki, Prawdziwa i katolicka nauka o sakramencie święceń dla potępienia błędów naszych czasów, red. A. Baron, H. Pietras, Kraków 2007 (DSP 4/2).

Sobór Watykański II, Dekret o posłudze i życiu kapłanów Presbyterorum ordinis, w: Sobór Watykański II, Konstytucje. Dekrety. Deklaracje, Poznań 2002, s. 487-517. 
Sobór Watykański II, Konstytucja dogmatyczna o Kościele Lumen gentium, w: Sobór Watykański II, Konstytucje. Dekrety. Deklaracje, Poznań 2002, s. 105-166.

Strzelczyk G., „Istota, a nie tylko stopniem” (LG 10). Hipoteza wyjaśnienia, „Śląskie Studia Historyczno-Teologiczne" 44 (2011) z. 1, s. 126-134.

Św. Hieronim ze Strydonu, Listy, t. 5, red. H. Pietras, Kraków 2013.

Św. Tomasz z Akwinu, Komentarz do Sentencji, https://www.corpusthomisticum. $\operatorname{org}(16.02 .2021)$.

Wojnarowicz P., Sakrament święceń i małżeństwa według motu proprio „Omnium in mentem” Benedykta XVI, „Kościół i Prawo” 3 (2014) nr 1, s. 109-121. 